\title{
INIERF-SPACQ
}

\section{PLANNING FROM PERCEPTIONS AND PREFERENCES FOR COMPOSITION OF TREE PLANTING ON SIDEWALKS}

\author{
PLANEJAMENTO A PARTIR DAS PERCEPÇÕES E PREFERÊNCIAS PARA A \\ COMPOSIÇÃO DO PLANTIO DE ÁRVORES NAS CALÇADAS
}

\section{PLANIFICACIÓN A PARTIR DE PERCEPCIONES Y PREFERENCIAS PARA LA COMPOSICIÓN DEL PLANTACIÓN DE ÁRBOLES EN LAS ACERAS}

\begin{abstract}
Sidnei Antonio Crovador Junior
Engenheiro Florestal e Mestrando do Programa de Pós-Graduação em Ciências Florestais da Universidade Estadual do Centro-Oeste - UNICENTRO. Laboratório de Silvicultura Urbana. junior.crovador85@gmail.com / http://orcid.org/0000-0002-2719-4832

\section{Rogério Bobrowski}

Doutor e Mestre em Engenharia Florestal pela Universidade Federal do Paraná - UFPR. Professor Adjunto do Departamento de Engenharia Florestal da Universidade Estadual do Centro-Oeste -

UNICENTRO/Campus Irati/Paraná. Laboratório de Silvicultura Urbana. rogerio@unicentro.br / http://orcid.org/0000-0003-4868-3376
\end{abstract}

Recebido para avaliação em 28/08/2019; Aceito para publicação em 06/10/2020.

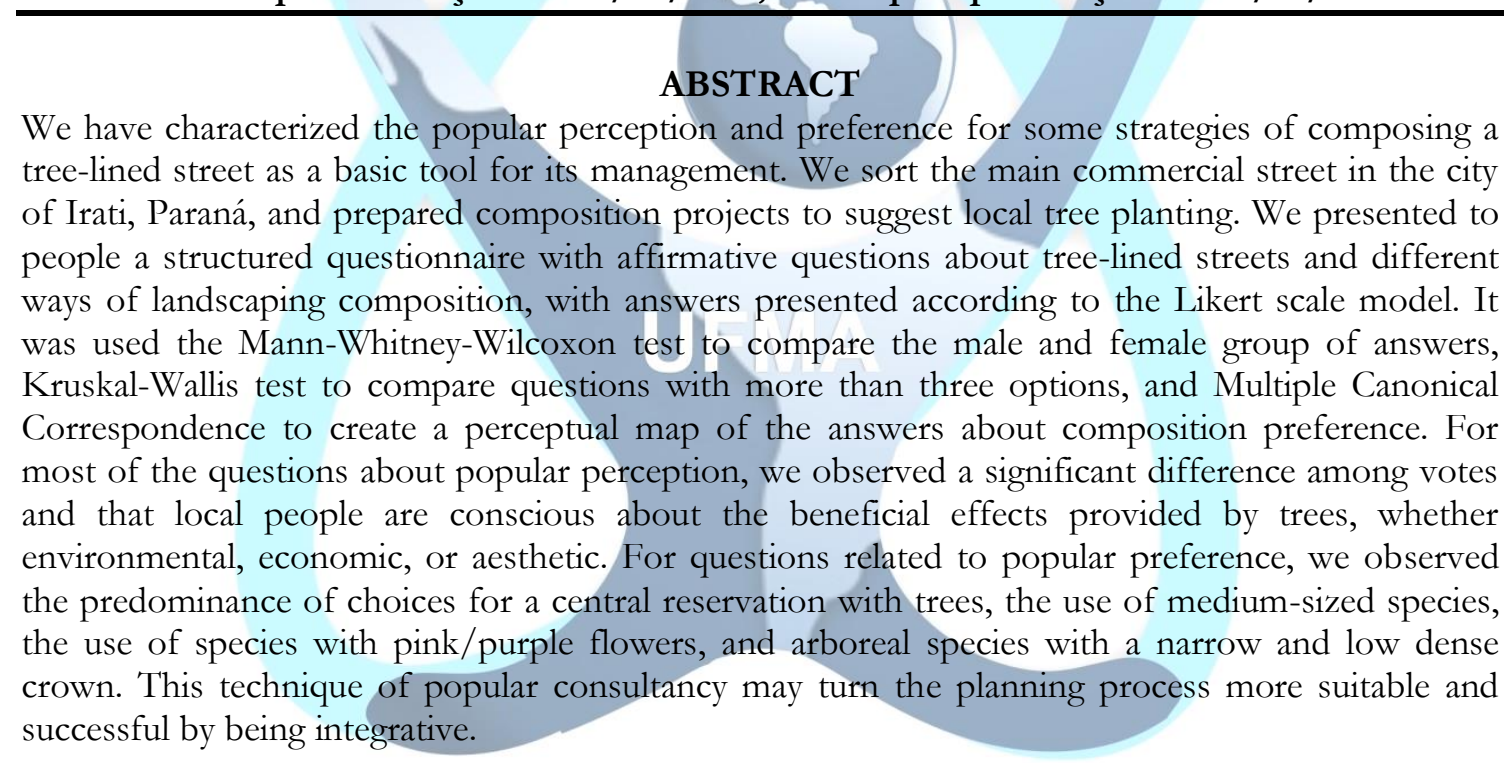

Keywords: Green Cities; Landscaping; Urban Environmental Management; Urban Forestry.

\section{RESUMO}

Caracterizou-se a percepção e preferência popular por formas de composição da arborização de calçadas como ferramenta básica de gestão. Escolheu-se a principal rua comercial de Irati, Paraná, para a qual foram elaborados projetos de composição para sugerir o plantio de árvores. Foi apresentado aos entrevistados um questionário estruturado contendo questões afirmativas sobre arborização de calçadas e diferentes formas de composição paisagística para a rua, com respostas apresentadas na escala de Likert. Utilizou-se o teste de Mann-Whitney-Wilcoxon para comparar os grupos masculino e feminino, o teste de Kruskal-Wallis para comparar as respostas com mais de 
|Sidnei Antonio Crovador Junior | Rogério Bobrowski |

três opções e Correspondência Canônica Múltipla, para mapeamento perceptual das respostas de preferência de composição. Para a maioria das questões relacionadas à percepção popular constatou-se diferença significativa entre os votos dados e que a população é consciente dos efeitos benéficos das árvores, sejam ambientais, econômicos ou estéticos. Para as questões relacionadas à preferência popular constatou-se predominância pela implantação de um canteiro central na rua, uso de espécies de médio porte, uso de espécies com flores de coloração rosa/roxa e espécies arbóreas com copa estreita e pouco densa. Esta técnica de consulta à população pode tornar o processo de planejamento mais adequado e exitoso por ser integrativo.

Palavras-chave: Cidades Verdes; Gestão Ambiental Urbana; Paisagismo; Silvicultura Urbana.

\section{RESUMEN}

Se caracterizó la percepción y preferencia popular por formas de composición de la forestación de las aceras como herramienta básica de gestión. Fue elegida la principal calle comercial de la ciudad de Irati, Paraná, a partir de la cual se elaboraron proyectos de composición para sugerir la plantación de los árboles. A los encuestados se les presentó un cuestionario estructurado conteniendo preguntas afirmativas sobre la forestación de las aceras y sobre distintas formas de la composición paisajística para la calle, con las respuestas presentadas en la escala de Likert. Fue utilizado la prueba Man-Whitney-Wilcoxon para comparar los grupos masculino y femenino, la prueba de Krustal-Wallis para comparar las respuestas con más de tres opciones y Correspondencia Canónica Múltiple para el mapeo perceptual de las respuestas con más de tres opciones de preferencia de composición. Para la mayoría de las cuestiones relacionadas a la percepción popular se encontró diferencias significativas entre los votos emitidos y que la población es consciente de los efectos beneficiosos de los árboles, sean ambientales, económicos o estéticos. Para las cuestiones relacionadas a la preferencia popular, se verificó el predominio por la implantación de un cantero central en la calle, uso de especies de tamaño mediano con la coloración rosa/morada y especies arbóreos con la copa angosta y poco densa. Esta técnica de consulta a la población puede hacer que el proceso de planificación sea más apropiado y exitoso por ser integrador.

Palabras-clave: Ciudades Verdes; Gestión Ambiental Urbana; Paisajismo; Silvicultura Urbana.

\section{INTRODUCTION}

Due to the expansion of urban settlement, induced by demand and supply of services and job opportunities, environmental and social problems have been increasing by the absence of planning or failure during the process (DU, 2016; QAID et al., 2016). As a result, problems such as deforestation for new real estate developments, construction of buildings on sensitive areas such as riverbanks and slopes, soil sealing, and changes in local biodiversity are challenging processes for urban ecology studies because they originate and contribute to some global environmental problems such as climate change (GRIMMOND, 2007; GRIMM et al., 2008).

Because of this, urban and environmental planning must be a tool of constant updating with adequate and efficient practices, through planning guidelines that guide the city to grow in a sustainable way. In this context, environmental planning, and more specifically, urban forest planning becomes an important task to maintain or improve the 
| Planning from pereptions and preferences for composition of tree planting on sidewalks |

|Sidnei Antonio Crovador Junior | Rogério Bobrowski|

quality of the environment and the life of inhabitants (MATSUOKA; KAPLAN, 2008; SARKAR et al., 2015; PLANT; SIPE, 2016).

The management of different forms of the urban forest (public squares, parks, and trees on sidewalks) must take into account planning tools that allow the analysis and planning of each one in a different and specific manner because in places as streets the number of structures and problems can be greater. Then, it must be done in order to provide environmental, social, economic, and aesthetic benefits aimed at the presence of trees in cities (KENNEY et al., 2011; MULLANEY et al., 2015).

Information about preferences and popular perception regarding attributes of composition is one strategy of participatory planning to help the management of trees on sidewalks (NG et al., 2015; BOBROWSKI; BIONDI, 2016; RUPER, 2017). Matsuoka and Kaplan (2008), based on the review of several articles, argued that people are very keen to take part in decisions that affect them, including public planning processes such as urban forest management. This kind of technical procedure aims to guide planning decisions in line with the wishes and desires of people living around the place to be planted or managed.

In this regard, Ruper (2017) used digital models of composition for trees on sidewalks and gardens, with different species diversity (complexity) and distribution of plants (coherence). As a result, he observed that there was a correlation between citizen's preference and the estimates of the complexity of the virtual landscape and that people prefer more diversified landscapes with an arrangement of plants in groups, instead of a formal composition with repetition or random rhythm.

Bobrowski and Biondi (2016), in a study about popular perception and preferences for the composition of tree-lined streets, concluded that people know some aesthetic attributes about trees on sidewalks and could appropriately answer questions by doing sensible correspondences. Besides, they found that people prefer compositions with trees of different species, alternately in a longitudinal view of the sidewalk, medium-sized trees, and yellow-flower trees. These popular preferences could be useful in the planning process of planting trees on sidewalks.

Therefore, as a general objective of this research, we aimed to evaluate the perception and preference for aesthetic and ecological attributes in the composition of plants on sidewalks of Irati, in order to help public agencies in the process of managing this public patrimony that is important to the quality of urban life. 
| Planning from pereptions and preferences for composition of tree planting on sidewalks |

|Sidnei Antonio Crovador Junior | Rogério Bobrowski|

\section{MATERIAL AND METHODS}

In this research, we chose Dr. Munhoz da Rocha Street that is one of the most important commercial areas of the city of Irati, Paraná. This city is in the south-central region of the state, $156 \mathrm{~km}$ from Curitiba, and inserted within the ecosystem of the Mixed Ombrophilous Forest, in the Atlantic Forest Biome.

From the variables of the urban structure, we considered the constraints imposed by the local infrastructure (wiring, marquises, corners,...) in order to design projects for planting trees on sidewalks of this street. We developed them considering the average width of sidewalks as $4.0 \mathrm{~m}$, the width of the street equal to $10.3 \mathrm{~m}$, the width of parking spaces equal to $2.0 \mathrm{~m}$, the average distance of the marquees over the sidewalk equal to 2.0 $\mathrm{m}$, and the average distance between lampposts equal to $25.0 \mathrm{~m}$. We used these projects in interviews regarding popular preference for composition (Figure 1).

In all compositions, we kept the same amount of elements (woody and herbaceous species) and the same amount of trees or the size of vines because the variety and diversity of elements in the composition (complexity) can influence the judgment of the interviewees (RUPER, 2017). 
| Planning from pereptions and preferences for composition of tree planting on sidewalks |

|Sidnei Antonio Crovador Junior | Rogério Bobrowski|

Figure 1 - Examples of the street layout in different transversal (A) and longitudinal (B) view, with details for Handroanthus heptaphyllus on the central reservation (A1 and B1), Myrsine coriacea on on-street parking (A2 and

A1.

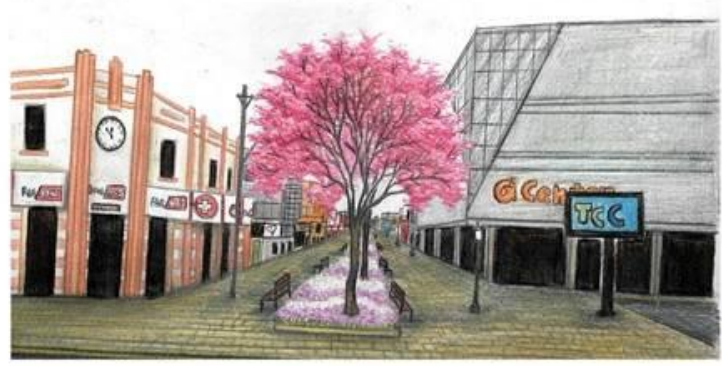

A2.

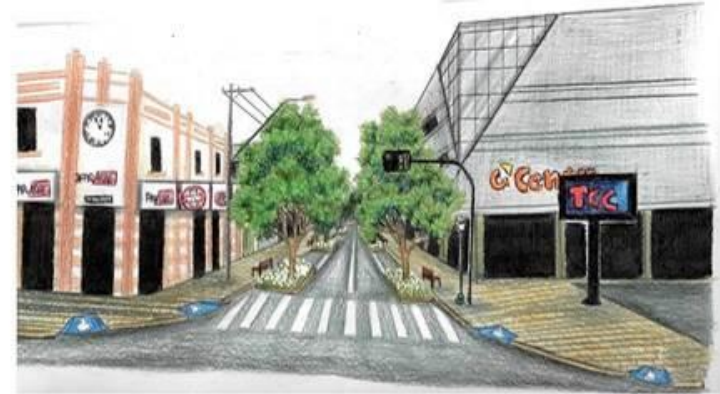

A3.

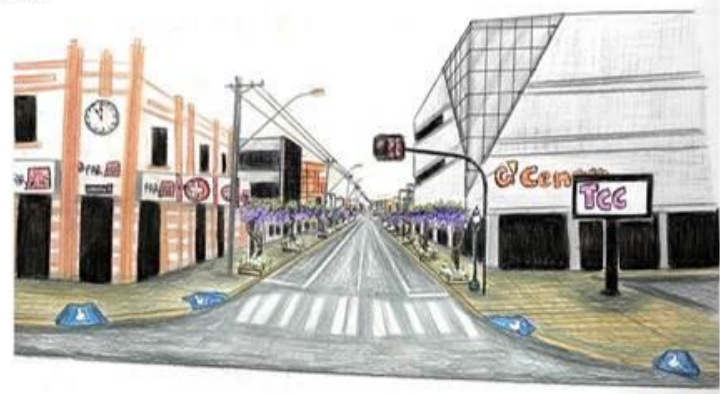

B1.

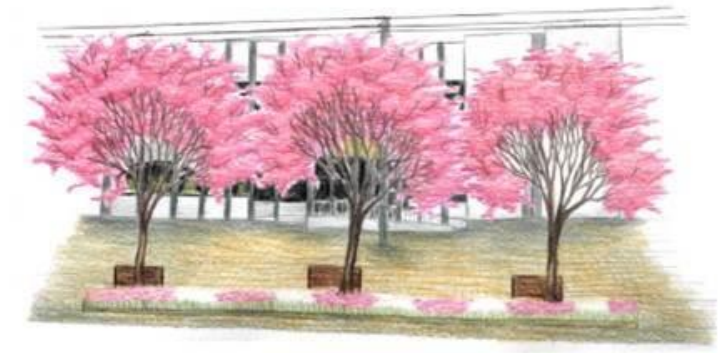

B2.

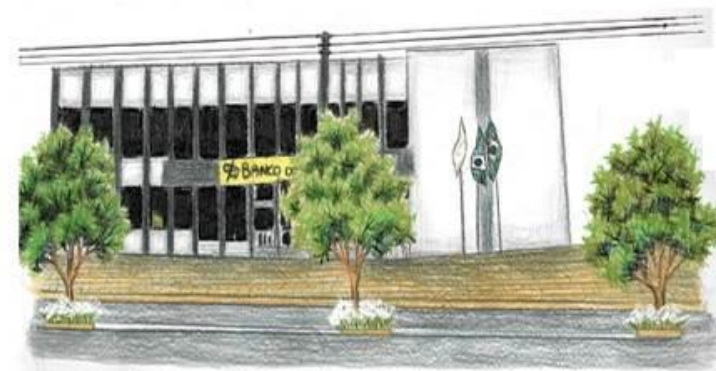

B3.

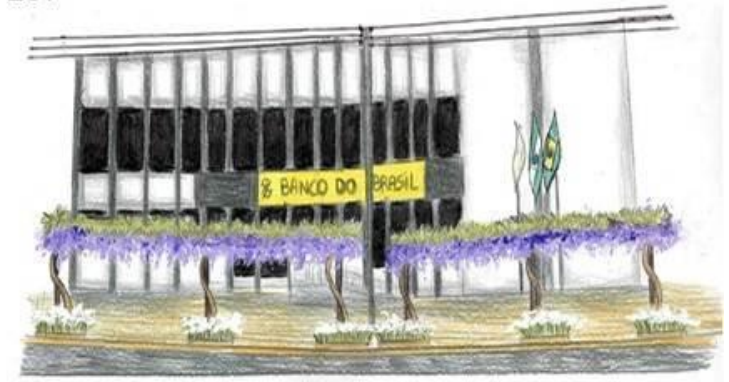

\section{First composition: trees on central reservation}

In this project, we considered planting trees on the central reservation of Dr. Munhoz da Rocha Street (Figure 1-A1), with limitations to the traffic. Because it presents $10.30 \mathrm{~m}$ of average width between curbs, we could use large, medium, or small-sized species. In addition, we proposed some flowering color variation by choosing different species. To analyze the preference for aesthetic characteristics, we chose the species Handroanthus heptaphyllus (Vell.) Mattos (purple trumpet tree), Handroanthus umbellatus (Sond.) Sand. Mattos (yellow trumpet tree), and Tabebuia roseoalba (Ridl.) Sandwith (white trumpet tree) which are commonly planted around cities in Brazil.

\section{Second composition: trees on on-street parking}


| Planning from pereptions and preferences for composition of tree planting on sidewalks |

|Sidnei Antonio Crovador Junior | Rogério Bobrowski|

In this project, we planned to plant trees on on-street parking spaces (Figure 1-A2) by using plots of $2.0 \mathrm{~m}$ width and $2.5 \mathrm{~m}$ length and about $10.0 \mathrm{~m}$ distant from each other, due to car entrances and lampposts. In this composition, regarding the species selection, we had to consider restriction distances for planting trees to avoid problems to lampposts, power lines, and marquees. Then, species should have a narrow crown spread. In order to analyze the preference for aesthetic composition characteristics, we chose the native species Myrsine coriacea (Sw.) R. Br. (capororoca), Eugenia involucrata Dc. (cerejeira), and Casearia decandra Jacq (cafezeiro).

\section{Third composition: vines on parking strip gardens}

Due to sidewalks had a reduced size ( $4.0 \mathrm{~m}$ of average width), with the presence of marquees, lampposts, and power lines over them, we chose a new model of landscape composition. For this, we proposed a wooden pergola along sidewalks (Figure 1-A3) with wooden posts $2.0-3.0 \mathrm{~m}$ distant and $2.5 \mathrm{~m}$ tall. In order to analyze the preference for aesthetic composition characteristics, we chose vine species like Wisteria floribunda (Willd.) DC. (japanese wisteria), Wisteria floribunda "alba" Lindl. (white japanese wisteria), and Laburnum anagyroides Medik. (golden rain) that could grow over the woody structure.

\section{Perception and preferences analysis}

We elaborated a structured questionnaire about project contents and divided it into two parts. The first one with affirmative questions related to citizen's perception of the role of trees on sidewalks (Figure 2). The second one with questions related to the interviewee's preferences regarding ways of composing the streetscape (Figure 3).

In questions that covered citizen's perception, interviewees had five options of answers that varied between very little and very much. For questions related to the preference of landscape composition, interviewees had three alternatives as options of choice, related to the forms of composition (Figure 3). We used the Likert scale as a pattern to the answers because of its easiness and flexibility, making it more practical for interviewees to demonstrate their degree of agreement or disagreement.

The questionnaire was made available to randomly chosen people who agreed to participate in the survey. The approach took place in places such as public squares, parks, schools, churches, and supermarkets, as well as at Dr. Munhoz da Rocha Street. 
| Planning from pereptions and preferences for composition of tree planting on sidewalks |

|Sidnei Antonio Crovador Junior | Rogério Bobrowski|

Figure 2 - Questionnaire developed to the evaluation of popular perception about basic attributes and role of trees on sidewalks.
Gender
(1) Male
(2) Female

\section{School level class}

(1) Elementaty school

(2) Incomplete high school

(3) Complete high school

(4) Incomplete higher education

(5) Complete higher education

\section{A) Questions related to perception about trees on sidewalks:}

1 - Every urban infrastructure (water supply, sewage system, light system) brings benefits to people, has its own cost and can cause damage. How much do you think trees planted on sidewalks can be understood as an urban infrastructure or green infrastructure?

\begin{tabular}{|c|c|c|c|c|}
\hline Very little & Little & Neutral & Much & Very much \\
\hline
\end{tabular}

2 - Do you agree that trees planted on sidewalks can bring benefits to the city and people?

\begin{tabular}{|c|c|c|c|c|}
\hline Very little & Little & Neutral & Much & Very much \\
\hline
\end{tabular}
- How much benefits do you think trees can bring?
\begin{tabular}{|c|c|c|c|c|}
\hline Very little & Little & Neutral & Much & Very much \\
\hline
\end{tabular}

4 - Trees planted on sidewalks can improve local microclimate (keep warm temperature and increase air humidity) and the environmental comfort?

\begin{tabular}{|c|c|c|c|c|}
\hline Very little & Little & Neutral & Much & Very much \\
\hline
\end{tabular}

5 - Changes in the leaf color or the flowering of trees can beautify the landscape of streets?

\begin{tabular}{|c|c|c|c|c|}
\hline Very little & Little & Neutral & Much & Very much \\
\hline
\end{tabular}

6 - Leaves and flowers falling on streets must be seen as a reason to avoid planting trees on sidewalks?

\begin{tabular}{|c|c|c|c|c|}
\hline Very little & Little & Neutral & Much & Very much \\
\hline
\end{tabular}

7 - A tree-lined street can improve people security by helping their moving around (as they have a better environmental comfort)?

\begin{tabular}{|c|c|c|c|c|}
\hline Very little & Little & Neutral & Much & Very much \\
\hline
\end{tabular}

8 - A tree-lined street can boost the valuation of properties?

\begin{tabular}{|c|c|c|c|c|}
\hline Very little & Little & Neutral & Much & Very much \\
\hline
\end{tabular}

9 - A tree-lined street can increase sales profit of the local trade?

\begin{tabular}{|c|c|c|c|c|}
\hline Very little & Little & Neutral & Much & Very much \\
\hline
\end{tabular}

10 - The presence of strip gardens and ornamental plants in the composition of a tree-lined street can help controlling floods?

\begin{tabular}{|c|c|c|c|c|}
\hline Very little & Little & Neutral & Much & Very much \\
\hline
\end{tabular}


| Planning from pereptions and preferences for composition of tree planting on sidewalks |

|Sidnei Antonio Crovador Junior | Rogério Bobrowski |

Figure 3 - Questionnaire developed to the evaluation of popular preference about composition attributes of trees on sidewalks.

\section{B) Questions related to preferences about tree-lined street composition:}

1- Which one of these transversal view compositions do you prefer?
(1) Trees on central reservation
(2) Trees on street parking
(3) Vines on parking strip gardens

2- What is your reason to this choice?

(1) It highlights the species and contrasts more intensely with the urban environment

(2) It is better distributed and offers the best street shading

(3) It is a new way to put plants on streets without taking up so much space

3- Among items of the first composition of question one, what size of tree do you prefer?

(1) Small size/ Tabebuia roseo-alba (white trumpet tree)

(2) Medium size/ Handroanthus umbellatus (purple trumpet tree)

(3) Large size/ Handroanthus heptaphyllus (yellow trumpet tree)

4- Why the chosen size is the most interesting?

(1) It represents a better stability and security to the pedestrian movement

(2) It provides more environmental advantages

(3) It better shows the aesthetic of species

5- Among items of the first composition, what is your favorite crown color during flowering season?
(1) Pink/purple
(2) Yellow
(3) White/beige

6- Why the chosen color is the most interesting?

(1) Because it shows the greatest contrasts to the landscape with a better focus on trees

(2) Because I believe this is the most beautiful

(3) Because it's the most common flowering color in the local ecosystem

7- Among items of the second composition of question one, which one do you prefer?
(1) Composition with Myrsine coriacea (Capororoca)
(2) Composition with Eugenia involucrata (Cerejeira)
(3) Composition with Casearia decandra (Cafezeiro)

8- Why the chosen composition is the most interesting?

(1) It highlights the aesthetics of the species

(2) It promotes the best shading to the street

(3) It is a common species in the local ecosystem

9- Among items of the third composition of question one, which one do you prefer?

(1) Purple/blue flowering color (japanese wisteria)

(2) White flowering color (white japanese wisteria)

(3) Yellow flowering color (golden rain)

10 - Why the chosen composition is the most interesting?

(1) Because it shows the greatest contrasts to the landscape

(2) Because I believe this is the most beautiful

(3) Because it's a common species used in the city

Each answer item from questionnaire one (Figure 2) was numbered from 1 to 5 (from very little to very much), in order to run statistical analysis. In the second 
| Planning from pereptions and preferences for composition of tree planting on sidewalks |

|Sidnei Antonio Crovador Junior | Rogério Bobrowski|

questionnaire (Figure 3), we did the same but using a scale between 1 and 3, as it had only three possible answers to choose from.

From data collected, we compiled matrices in a spreadsheet prepared in the software Microsoft Excel 2013, by using each item chose by each person in each question. In software $\mathrm{R}$, statistical analyzes were performed using three different tests. MannWhitney-Wilcoxon test was used to compare two unpaired groups related to the responses obtained between the male and female groups. Kruskal-Wallis test was used to compare three or more independent samples related to the answers given to the same question. Multiple Canonical Correspondence Analysis, to map and interpret answers related to citizens' preferences for composition.

\section{RESULTS}

We applied 333 questionnaires to 137 men and 196 women that were interviewed in different places of the city, which was an acceptable number of citizens that contributed to this study. According to Alreck and Settle (2004), in studies about the attitudes of a group of more than 300 people, there is a $95 \%$ probability that the variation is low than $10 \%$ of the population mean.

From these number of interviewees, $30.93 \%$ of them belonged to the class $10-20$ years old, $24.92 \%$ to the class 20 - 30 years old, $13.51 \%$ to the class 30 - 40 years old, $12.91 \%$ to the class 40 - 50 years old and $17.71 \%$ to the class above 50 years old. Regarding the school level, $26.42 \%$ of people assumed to have an elementary education, $19.51 \%$ an incomplete secondary education, $15.61 \%$ a complete one, $25.22 \%$ an incomplete higher education, and $13.21 \%$ a complete one.

A significant difference $(p<0.05)$ was observed for votes given to the items of all questions related to popular perception about trees on sidewalks (Table 1 and Figure 2).

From questions, one to five, the sum of votes given to the items very and very much represents more than $90 \%$ of data, which expresses an intense agreement with the sentences presented to interviewees.

In questions eight to ten, we observed that there were also many votes for the items very and very much. However, votes given to the items neutral and little suggest an expressive demonstration of doubt and slight disagreement with the statements presented in these questions. 
| Planning from pereptions and preferences for composition of tree planting on sidewalks |

|Sidnei Antonio Crovador Junior | Rogério Bobrowski |

On the other hand, in question six we noticed that people intensily disagreed with the affirmative made in the sentence since more than $90 \%$ of the votes were given to the items little and very little.

Table 1 - Proportional votes (\%) given to each item for questions related to general perception about the role of trees on sidewalks, and for questions related to the preference for composition. Data were distributed according to school level classes.

\begin{tabular}{|c|c|c|c|c|c|c|c|c|c|c|c|c|c|}
\hline \multirow{3}{*}{ Q } & \multicolumn{7}{|c|}{ Perception about trees on sidewalks } & \multicolumn{6}{|c|}{ Preference for composition } \\
\hline & \multicolumn{5}{|c|}{ Answer items } & \multirow{2}{*}{$\chi^{2}$} & \multirow{2}{*}{$\mathrm{p}$} & \multirow{2}{*}{ Q } & \multicolumn{3}{|c|}{ Answer items } & \multirow{2}{*}{$\chi^{2}$} & \multirow{2}{*}{$\mathrm{p}$} \\
\hline & $\mathrm{V} 1$ & Lt & $\mathrm{Nt}$ & $\mathrm{Mh}$ & $\mathrm{Vm}$ & & & & 1 & 2 & 3 & & \\
\hline 1 & 0.00 & 2.40 & 6.01 & 35.44 & 56.16 & 20.43 & $4.10^{-4}$ & 1 & 54.05 & 32.73 & 13.21 & 11.20 & $3.69^{-3}$ \\
\hline 2 & 0.00 & 1.50 & 6.31 & 31.53 & 60.66 & 22.35 & $1.71^{-4}$ & 2 & 45.05 & 28.23 & 26.73 & 5.53 & $6.30^{-2}$ \\
\hline 3 & 0.00 & 2.10 & 6.01 & 32.43 & 59.46 & 21.89 & $2.11^{-4}$ & 3 & 8.71 & 60.96 & 30.33 & 10.55 & $5.11^{-3}$ \\
\hline 4 & 0.00 & 0.30 & 3.30 & 31.53 & 64.86 & 21.49 & $2.53^{-4}$ & 4 & 39.34 & 30.63 & 30.03 & 9.98 & $6.09^{-1}$ \\
\hline 5 & 0.30 & 2.10 & 5.71 & 44.14 & 47.75 & 20.49 & $3.99^{-4}$ & 5 & 51.05 & 36.94 & 12.01 & 9.69 & $7.87^{-3}$ \\
\hline 6 & 36.04 & 58.56 & 0.00 & 3.60 & 1.80 & 21.39 & $2.65^{-3}$ & 6 & 35.74 & 52.55 & 11.71 & 9.26 & $9.74^{-3}$ \\
\hline 7 & 9.61 & 30.93 & 34.23 & 18.32 & 6.91 & 16.32 & $2.61^{-3}$ & 7 & 64.26 & 26.13 & 9.61 & 12.32 & $2.11^{-3}$ \\
\hline 8 & 3.90 & 15.62 & 21.32 & 39.04 & 20.12 & 14.49 & $5.69^{-3}$ & 8 & 39.04 & 44.74 & 16.22 & 4.88 & $8.70^{-2}$ \\
\hline 9 & 4.50 & 20.42 & 23.12 & 39.04 & 12.91 & 16.81 & $2.10^{-3}$ & 9 & 43.24 & 20.42 & 36.34 & 6.72 & $3.48^{-2}$ \\
\hline 10 & 3.60 & 14.11 & 10.21 & 43.24 & 28.83 & 17.61 & $1.47^{-3}$ & 10 & 47.75 & 42.94 & 9.31 & 9.04 & $1.09^{-2}$ \\
\hline
\end{tabular}

In question seven, although we observed a significant difference among votes given to the influence of trees on sidewalks over the public security, there was a predominance of doubt or disagreement, since most of the people voted on the item neutral, followed by the item little.

Concerning the preference for the composition of trees on sidewalks, a significant difference $(\mathrm{p}<0.05)$ was observed among votes given to all questions, except for questions two, four, and eight (Table 1), which deal with answers related to questions one, three, and seven respectively.

For question one, which presented transversal compositions for the street, most people chose the composition with trees in the central reservation (Table 1). Most of the respondents justified their choice through item one of question two "It highlights the species and contrasts more intensely with the urban environment". It can be seen that for people who chose trees on central reservation (Figure 4), there is a greater correspondence with item one of question two, which characterizes the attributes of this composition, with trees being able to grow without physical barriers, spread their crown in the place and show their real shape, maximum spread, size and beauty in mature phase.

Also relevant is the correspondence observed for people who chose the composition with vines on sidewalks, and the justification that this is an innovative way of having plants on sidewalks without taking up so much space (item three of question two). This form of composition can be an aesthetical and technical option due to spatial 
|Sidnei Antonio Crovador Junior | Rogério Bobrowski|

restrictions such as narrow sidewalks and the presence of marquees as occurs in the street selected for the study.

In question three, most people voted in item two, concerning medium-sized trees such as Handroanthus umbellatus. In general, they justify their options as this composition would represent better stability and safety to pedestrians. However, the number of votes given to this justification is similar to the others. Graphical analysis (Figure 4) shows that for the most voted composition (medium-sized species) there is no obvious match with any item of question four. However, for those who chose the composition with large species, such as Handroanthus heptaphyllus, there is a greater correspondence with the justification that this option would be the one to add greater environmental advantages to the place.

Figure 4 - Multiple canonical correspondence analysis for questions about preferences for composition of trees on sidewalks (Q), with data distributed according to school level classes (E).

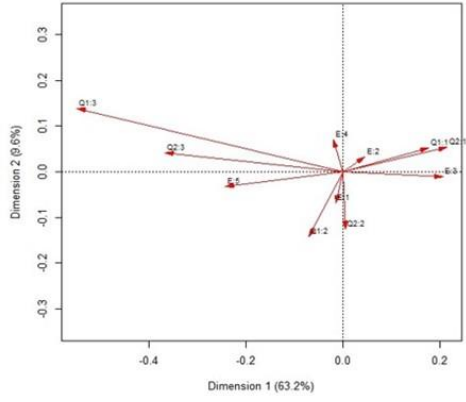

Questions 1 and 2

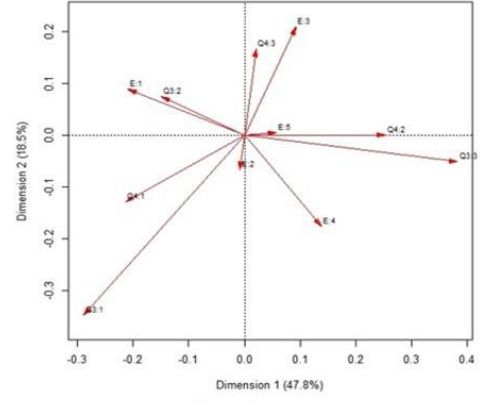

Questions 3 and 4

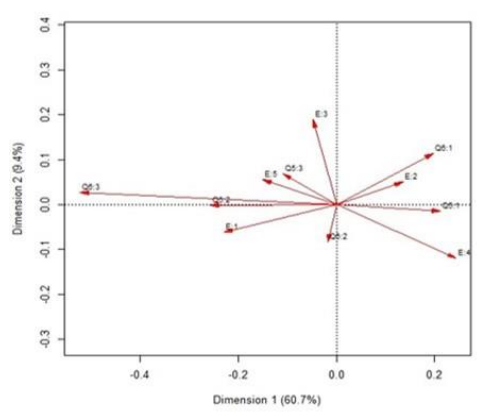

Questions 5 and 6

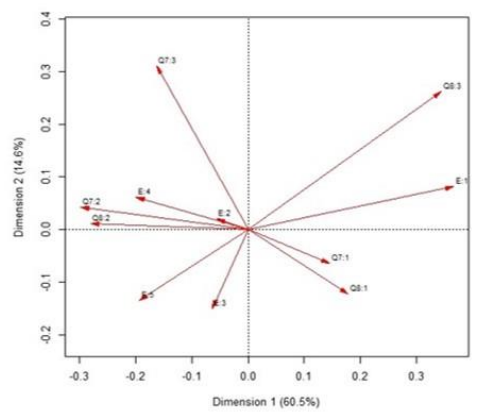

Questions 7 and 8

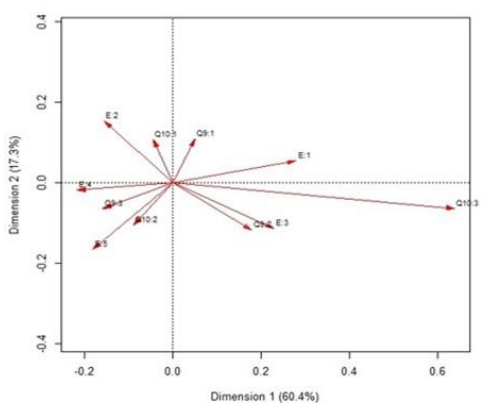

Questions 9 and 10

Regarding the preference for a particular flower color (question five), most people opted for trees with pink/purple flowering, followed by those who voted for yellow flowering. The most voted justification was that they believe to be the most beautiful option, but there was no evident correspondence between this justification and the choice of flower color most voted (Figure 4).

The choice of Myrsine coriacea (capororoca) predominated in the composition of plots distributed on on-street parking spaces, mainly because this species has a compact crown (question seven). As justification, most people opted for the answer "It promotes the best shading to the street". However, graphical analysis shows a correspondence 
| Planning from pereptions and preferences for composition of tree planting on sidewalks |

|Sidnei Antonio Crovador Junior | Rogério Bobrowski|

between the votes given for the species Myrsine coriacea and the justification "It highlights the aesthetics of the species". Among votes given for the species Eugenia involucrata (native cherry tree), there was correspondence with the justification "It promotes the best shading to the street". Although there is a potential for planting on sidewalks, these two species have not been reported in inventories carried out in Brazilian cities.

In question nine, the most chosen vine species was the one with a purple color inflorescence (Wisteria floribunda), followed by the yellow one (Laburnum anagyroides). The justification most voted was "Because it shows the greatest contrasts with the landscape". Graphical analysis (Figure 4) shows a better correspondence between the votes for the species Laburnum anagyroides and the justification "Because I believe this is the most beautiful". These ornamental species of vines are popular because they are found in residential and commercial gardens in the city of Irati, composing fences or covering pergolas.

\section{DISCUSSION}

For school-level classes and age classes, no significant difference $(p=0.3125)$ was found between the number of male and female respondents. It is a positive result of the research since genders can present different preferences and perceptions (TUAN, 2012). Thus, distinctions about perception and preference between genders in this research are not related to differences between the number of people belonging to each group. Because of the best uniformity of distribution of people in the school level classes, we used them as a reference to distribute data for use in the canonical correspondence analysis.

Questions 1 to 5 and 10 dealt with general perception issues about the environmental benefits offered by trees. Since the majority of respondents chose the items very much, it can be assumed that they demonstrated a correct opinion about the function and benefits of trees in urban centers, mainly because they consider trees on sidewalks as part of the urban infrastructure.

In this regard, Zölch et al. (2016) argue that urban green infrastructures have been seen as a mean to mitigate the effects of urban heat islands and climate change, but that the real contribution of each type of green infrastructure is not yet known, especially regarding public management challenges.

These data are important information because they show a successful perception of people in the city, regarding the importance of trees, their roles, and their benefits in cities. However, to the city of Irati, there are no data available about the characteristics of trees on 
| Planning from pereptions and preferences for composition of tree planting on sidewalks |

|Sidnei Antonio Crovador Junior | Rogério Bobrowski|

sidewalks such as the number of trees, main species, and general condition, nor the contribution of existing trees concerning environmental effects such as microclimate regulation and runoff avoidance.

In question six, the expressive agreement made by interviewees demonstrates that people have a sensible perception that trees lose their leaves as part of their natural growth cycle and that this is not a problem for the city, since the fall of leaves during the winter is a positive aspect regarding decisions for composing trees on sidewalks, mainly in cities with severe winters such as Irati. However, for people in some Brazilian cities leaves fall can be seen as a negative aspect of trees, due to inconvenient dirty on streets or to disruption in the rainwater harvesting (SOUZA et al., 2013; TEIXEIRA; SAMMARCO, 2014), despite the commitment of public agencies to cleaning public spaces.

The vast majority of the interviewed people (65.16\%) opted for the little and neutral responses items in question seven. It may indicate a lack of suitable knowledge about the subject. Facing trees on sidewalks as a component of insecurity is something persistent in the perception of the Brazilian population. Some studies show that people think tree canopy can darken the public way and bring insecurity (RODOLFO JUNIOR et al., 2008; SABBAGH, 2011). However, public road safety depends on factors such as the adequacy of public lighting for pedestrians, proper pruning to reduce crown density, the intensity of traffic of people, and the quality of house maintenance that can inhibit the action of criminals (DONOVAN; PRESTEMON, 2012).

Although most respondents understand that trees can bring economic benefits (question eight), about $20 \%$ of them still believe that trees on sidewalks do not add economic benefits to the city. In contrast to this, studies carried out in the United States and Australia (SANDER et al., 2010; PANDIT et al., 2013) show that the canopy cover close to houses or on public roads increases the value of properties, with prices significantly greater in relation to the same condition without the presence of trees.

In this research, the preference for the composition with trees in the central reservation differs from the results observed by $\mathrm{Ng}$ et al. (2015), in Hong Kong, China, where people preferred a layout with trees on both sides of the street rather than in the central reservation. In this case, it is interesting to highlight that different preferences and perceptions can be cultural aspects (TUAN, 2012) and that we must consider this to avoid generalizations for the composition of trees on sidewalks.

The popular preference for medium-sized trees is a result similar to one reported by Souza et al. (2013). They found that in the city of Alegre, Espírito Santo, Brazil, there was a preference for medium-sized trees because people considered that this option would 
| Planning from pereptions and preferences for composition of tree planting on sidewalks |

|Sidnei Antonio Crovador Junior | Rogério Bobrowski|

reduce damages to power lines and buildings. Likewise, this was the choice preferred by the interviewees regarding the composition of trees on sidewalks in the city of Melbourne, Australia (WILLIAMS, 2002). However, according to Bobrowski and Biondi (2016), this kind of tree size may be inconvenient under power lines because trees tend not to overpass the medium voltage grid or tend to stay around the telecommunication network. Because of this, pruning practices can become more frequent, and the costs of this practice become more expensive.

Thus, we noticed that people are aware of the advantages offered by trees, knowing that the larger the area of canopy cover, the greater the environmental advantages offered by trees (MULLANEY et al., 2015). However, despite having this awareness about environmental advantages, it is notable that safety concerns still prevail.

Most people chose the pink/purple flower design in this research (Table 1), although votes almost have the same relative frequencies to Bobrowski and Biondi (2016), in an analysis of preferences for the composition of different aesthetic and ecological attributes of trees on sidewalks in different Brazilian cities. They found that interviewees chose yellow flowers $(46.88 \%)$ when compared to those trees with pink/purple $(42.33 \%)$ or white $(10.80 \%)$ flower colors.

The correspondence found between the votes of people who chose the yellow flowers and the justification that this would be the color of flowering that is the most common in local species may be related to the remembrance of two facts. The first one, the symbolic tree of the country, Paubrasilia echinata (Pau-Brazil), according to Federal Law $6607 / 1978$. Second, to some species of yellow trumpet trees that are considered the symbolic flower of the country, such as Handroanthus vellosoi, Handroanthus albus, Handroanthus chrysotrichus, Handroanthus serratifolius, and Handroanthus ochraceus. All these species, during early spring, present an intense and expressive form of yellow flowering in a leafless crown, which shows an intense contrast with the local landscape.

Through the analysis of this question, we observed that the majority of people from Irati prefers forest species with flowering colors that stand out in the landscape, with a great rejection for neutral colors such as white. Warm colors such as yellow, orange, red, and purple have vibrant, warm and active properties while cold colors such as blue, green, and white are related to passivity, kindness, and serenity (CHEBAT; MORRIN, 2007; SCHLOSS; PALMER, 2011). Both colors, pink and yellow, contrast with monotonous and gray colors that make up the urban centers, which draws attention to the plant element at the time of flowering. 
| Planning from pereptions and preferences for composition of tree planting on sidewalks |

|Sidnei Antonio Crovador Junior | Rogério Bobrowski|

\section{CONCLUSIONS}

The population of Irati has an adequate perception regarding the needs to plant trees in the city, as well as they are aware of the beneficial effects provided by trees.

Regarding preferences for composition, we noticed that the choices made were justified appropriately and coherently. From these results follow some preference tendencies: 1) plant trees in a central reservation; 2) use medium-sized tree species; 3) use species with intense color flowers, such as pink/purple or even yellow; 4) use species with a narrow, dense crown such as Myrsine coriacea.

We can also emphasize that this survey technique can make the planning for urban forest planting more appropriate and successful by integrating citizens as part of the process.

\section{REFERENCES}

ALRECK, P. L.; SETTLE, R. B. The survey research handbook. 3. ed. New York: McGraw-Hill, 2004.

BOBROWSKI, R.; BIONDI, D. Percepção e preferência popular por atributos estéticos e ecológicos na composição da arborização de ruas. Floresta, v. 46, n. 1, p. 123-133, 2016.

CHEBAT, J.; MORRIN, M. Colors and cultures: exploring the effects of mall décor on consumer perceptions. Journal of Business Research, v. 60, n. 3, p. 189-196, 2007.

DONOVAN, G. H.; PRESTEMON, J. P. The effect of trees on crime in Portland, Oregon. Environment and Behavior, v. 44, n. 1, p. 3-30, 2012.

DU, R. Urban growth: changes, management, and problems in large cities of southeast China. Frontiers of Architectural Research, v. 5, n. 3, p. 290-300, 2016.

GRIMM, N. B.; FAETH, S. H.; GOLUBIEWSKI, N. E.; REDMAN, C. L.; WU, J.; BAI, X.; BRIGGS, J. M. Global change and the ecology of cities. Science, v. 319, n. 5864, p. 756-760, 2008.

GRIMMOND, S. Urbanization and global environmental change: local effects of urban warming. The geographical journal, v. 173, n. 1, p. 83-88, 2007.

KENNEY, W. A.; VAN WASSENAER, P. J. E.; SATEL, A. L. Criteria and indicators for strategic urban forest planning and management. Arboriculture \& Urban Forestry, v. 17, n. 3, p. 108-117, 2011.

MATSUOKA, R. H.; KAPLAN, R. People needs in the urban landscape: analysis of landscape and urban planning contributions. Landscape and Urban Planning, v. 84, n. 1, p. 7-19, 2008. 
MULLANEY, J.; LUCKE, T.; TRUEMAN, S. J. A review of benefits and challenges in growing street trees in paved urban environments. Landscape and Urban Planning, v. 134, n. 2, p. 157-166, 2015.

NG, W.; CHAU, C.; POWELL, G.; LEUNG, T. Preferences for street configuration and street tree planting in urban Hong Kong. Urban Forestry \& Urban Greening, v. 14, n. 1, p. 30-38, 2015.

PANDIT, R.; POLYAKOV, M.; TAPSUWAN, S.; MORAN, T. The effect of street trees on property value in Perth, Western Australia. Landscape and Urban Planning, v. 110, n. 2, p. 134-142, 2013.

PLANT, L.; SIPE, N. Adapting and applying evidence-gathering techniques for planning and investment in street trees: A case study from Brisbane, Australia. Urban Forestry \& Urban Greening, v. 19, n. 5, p. 79-87, 2016.

QAID, A.; LAMIT, H. B.; OSSEN, D. R.; SHAHMINAN, R. N. R. Urban heat island and thermal comfort conditions at microclimate scale in a tropical planned city. Energy and Buildings, v. 133, n. 5, p. 577-595, 2016.

RODOLFO JUNIOR, F.; MELO, R. R.; CUNHA, T. A.; STANGERLIN, D. M. Análise da arborização urbana em bairros na cidade de Pombal no Estado da Paraíba. Revista da Sociedade Brasileira de Arborização Urbana, v. 3, n. 4, p. 3-19, 2008.

RUPER, R. Evaluations of landscape preference, complexity, and coherence for designed digital landscape models. Landscape and Urban Planning, v. 157, n. 1, p. 407-421, 2017.

SABBAGH, R. Arborização urbana no bairro Mario Dedini em Piracicaba. Revista da Sociedade Brasileira de Arborização Urbana, v. 6, n. 4, p. 90-106, 2011.

SANDER, H.; POLASKY, S.; HAIGHT, R. G. The value of urban tree cover: a hedonic property pricemodel in Ramsey and Dakota Counties, Minnesota, USA. Ecological Economics, v. 69, n. 8, p. 1646-1656, 2010.

SARKAR, C.; WEBSTER, C.; PRYOR, M.; TANG, D.; MELBOURNE, S.; ZHANG, X.; JIANZHENG, L. Exploring associations between urban green, street design and walking: results from the greater London boroughs. Landscape and Urban Planning, v. 143, n. 11, p. 112-125, 2015.

SCHLOSS, K. B.; PALMER, S. E. Aesthetic response to color combinations: preference, harmony, and similarity. Attention, Perception, \& Psychophysics, v. 73, n. 2, p. 551-571, 2011.

SOUZA, S. M.; CARDOSO, A. L.; SILVA, A. G. Estudo da percepção da população sobre a arborização urbana, no município de Alegre-ES. Revista da Sociedade Brasileira de Arborização Urbana, v. 8, n. 2, p. 68-85, 2013.

TEIXEIRA, T.; SAMMARCO, Y. M. Educomunicação para a arborização urbana na bacia Tietê-Jacaré. Revista da Sociedade Brasileira de Arborização Urbana, v. 9, n. 2, p. 55-76, 2014. 
|Sidnei Antonio Crovador Junior | Rogério Bobrowski|

TUAN, Y. Topofilia: um estudo da percepção, atitudes e valores do meio ambiente. Londrina: Eduel, 2012.

WILLIAMS, K. Exploring resident preferences for street trees in Melbourne, Australia. Journal of Arboriculture, v.2 8, n. 4, p. 161-170, 2002.

ZÖLCH, T.; MADERSPACHER, J.; WAMSLER, C.; PAULEIT, S. Using green infrastructure for urban climate-proofing: an evaluation of heat mitigation measures at the micro-scale. Urban Forestry \& Urban Greening, v. 20, n. 6, p. 305-316, 2016.

\section{Como citar este artigo:}

\section{ABNT}

CROVADOR JUNIOR, S. A.; BOBROWSKI, R. Planning from pereptions and preferences for composition of tree planting on sidewalks. InterEspaço: Revista de Geografia e Interdisciplinaridade, v. 6, e202022, 2020. Available in: <http://dx.doi.org/10.18764/2446-6549.e202022>. Access in: 25 jan. 2020.

\section{APA:}

Crovador Junior, S. A., \& Bobrowski, R. (2020). Planning from pereptions and preferences for composition of tree planting on sidewalks. InterEspaço: Revista de Geografia e Interdisciplinaridade, v. 6, e202022. Accessed January 25th, 2020, in http://dx.doi.org/10.18764/2446-6549.e202022

\section{cc) creative}

This is an open access article under the CC BY Creative Commons 4.0 license.

Copyright (C) 2020, Universidade Federal do Maranhão.

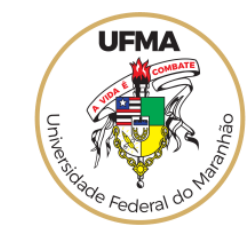

